\title{
Expression of Hepatocyte Growth Factor/Scatter Factor, Its Receptor, c-met, and Tissue-Type Plasminogen Activator during Development of the Murine Olfactory System
}

\author{
Douglas P. Thewke and Nicholas W. Seeds \\ Neuroscience Program and Department of Biochemistry/Biophysics and Genetics, University of Colorado Health \\ Sciences Center, Denver, Colorado 80262
}

The expression of hepatocyte growth factor/scatter factor (HGF/SF) and its receptor, the c-met proto-oncogene product, was examined by in situ hybridization in the developing and adult murine olfactory system and compared with the expression of a known activator of HGF/SF, tissue-type plasminogen activator (tPA). In the developing olfactory canal, expression of both c-met and tPA was observed in the olfactory neuroepithelium, whereas HGF/SF expression appeared to be confined to the mucosa adjacent to the neuroepithelium. During development of the olfactory bulb, HGF/SF and tPA were expressed within the rostral migratory pathway leading to the olfactory bulb, whereas c-met expression was observed in the mitral cell layer (MCL) of the olfactory bulb and in the anterior olfactory nucleus. In the adult olfactory bulb, expression of HGF/SF was restricted to the periglomerular region of the glomerular layer, whereas c-met was expressed in the MCL and olfactory nerve fiber layers (ONL). tPA expression in the adult olfactory bulb was observed in the ONL, MCL, and granule cell layers. Therefore, tPA expression was relatively coincident with the expression of HGF/SF and/or c-met in the appropriate projection patterns of the developing and adult olfactory system. In addition, antibodies against tPA inhibited the olfactory bulb extractmediated cleavage of single-chain HGF/SF. These results suggest that tPA may play a regulatory role in the development and maintenance of the olfactory system by activating HGF/SF in the immediate vicinity of its receptor.

Key words: hepatocyte growth factor; c-met; tissue-type plasminogen activator; olfactory system; olfactory bulb
The development of the mammalian CNS is a complex process involving extensive tissue remodeling, neuronal and nonneuronal cell migration, and neurite outgrowth; processes for which the activity of plasminogen activators (PAs) have been implicated. PAs are believed to aid in these processes by locally degrading the proteins involved in cell-cell and cell-matrix contacts. (Hart and Rehmetulla, 1988; Saksela and Rifkin, 1988; Seeds et al., 1990). Although there is substantial evidence supporting this role, the widespread and differential expression of PAs throughout the CNS suggests a diversity of possible functions. The fact that PAs can activate several latent growth factors raises the possibility that PAs may play a much broader role in regulating CNS processes than previously imagined (Campbell et al., 1992; Brauer and Yee, 1993).

One such growth factor, hepatocyte growth factor/scatter factor (HGF/SF), can elicit a variety of responses including mitogenic and motogenic activities from cells expressing its receptor, the $c$-met proto-oncogene product (Rubin et al., 1993). Expression of $\mathrm{HGF} / \mathrm{SF}$ and $c$-met is essential for development, because deleting either gene in mice produces embryonic lethality (Bladt et al., 1995; Schmidt et al., 1995; Uehara et al., 1995). HGF/SF has been

\footnotetext{
Received May 22, 1996; revised Aug. 15, 1996; accepted Aug. 19, 1996.

This work was supported by National Institutes of Health Grants NS09818 (N.W.S.) and T32-NS07083 (D.P.T.) and by National Science Foundation Grant IBN-9630458 (N.W.S.). N.W.S. is a Jacob Javits Investigator of the National Institute of Neurological Disorders and Stroke. We thank Dr. Steven Hayden for his helpful comments and suggestions. We also thank Susan Haffke for her help with tissue sectioning as well as Carey Miller and Darcy Williams for their valuable technical assistance.

Correspondence should be addressed to Dr. Nicholas W. Seeds, Neuroscience Program and Department of Biochemistry/Biophysics and Genetics, University of Colorado Health Sciences Center, 4200 East 9th Avenue, B-138, Denver, CO 80262. Copyright (C) 1996 Society for Neuroscience $0270-6474 / 96 / 166933-12 \$ 05.00 / 0$
}

implicated in the development and regeneration of several organs of epithelial origin (Santos et al., 1994; Schmidt et al., 1995; Woolf et al., 1995) and in the migration of myogenic precursor cells (Bladt et al., 1995). Although HGF/SF is expressed in brain (Jung et al., 1994), its function in the CNS is currently unknown; however, murine septal neurons in culture respond to $\mathrm{HGF} / \mathrm{SF}$ by increasing the level of $c$-fos transcripts (Jung et al., 1994).

$\mathrm{HGF} / \mathrm{SF}$ is secreted into the extracellular matrix as an inactive single-chain precursor, proHGF/SF. The biologically active form of $\mathrm{HGF} / \mathrm{SF}$ is produced by proteolytic processing of $\mathrm{proHGF} / \mathrm{SF}$ (Nakamura et al., 1989; Naka et al., 1992). In vitro, both urokinase-type PA (uPA) and tissue-type PA (tPA), as well as another protease related to blood coagulation factor XII, have been shown to cleave and activate proHGF/SF (Naldini et al., 1992; Mars et al., 1993). In liver, partial hepatectomy results in a rapid increase in the active form of $\mathrm{HGF} / \mathrm{SF}$, which is paralleled by an increase in uPA activity, suggesting that uPA serves as an activator of HGF/SF in liver (Mars et al., 1995).

The presence of $\mathrm{HGF} / \mathrm{SF}$ and/or $c$-met in the developing olfactory system (Sonnenberg et al., 1993) appears similar to the expression of tPA mRNA in the olfactory canal (OC) (Friedman and Seeds, 1994). The possibility that tPA may play a regulatory role in the development and/or maintenance of some structures of the olfactory system by activating HGF/SF was explored by defining more precisely the elements of the developing and adult murine olfactory system that express $\mathrm{HGF} / \mathrm{SF}$, c-met, and tPA mRNA and correlating their spatial and temporal distributions with developmental events in the olfactory system. A brief preliminary report of some of these findings has appeared previously (Thewke and Seeds, 1995). 


\section{MATERIALS AND METHODS}

Animals. All animal experiments were conducted according to an offcially approved institutional protocol. Adult and postnatal C57Bl/6 mice were killed with $\mathrm{CO}_{2}$ gas. The tissues were rapidly excised and immediately snap-frozen in 2 -methylbutane at $-35^{\circ} \mathrm{C}$. Tissues were then kept at $-70^{\circ} \mathrm{C}$ until use. Fetal mice were obtained after controlled mating for 12 hr. The morning after conception was defined as $0.5 \mathrm{~d}$.

Plasmids and probes. The mouse tPA cDNA vector $\mathrm{pK} 2 \mathrm{C} 3 \mathrm{z}$, containing a 515 bp fragment encompassing part of the coding sequence for the mouse tPA kringle 2 and catalytic domains, has been described previously (Friedman and Seeds, 1994). HGF/SF and c-met partial cDNA clones were obtained by RT-PCR of total mouse liver RNA using the following primers essentially as described by Kawasaki (1990): HGF/SF sense primer 5'-CGAAATCCTCGAGGGGAAGAAGGG-3' (535-559), HGF/SF antisense primer $5^{\prime}$-CCAACGCTGACAGGGAATTCCATTC-3' (965-990) sequence, and nucleotide numbers as in Lee et al. (1993); c-met sense primer 5'-GGGACTGCAGCAGCAAAGC-3' (296-314), c-met antisense primer 5'-GTCTGAGCATCTAGAGTTTCC-3' (795-815) sequence, and nucleotide numbers as in Chan et al. (1988). RT-PCR products were fractionated on $2 \%$ agarose gels, isolated, and subcloned into pGEM3z (Promega, Madison, WI) by standard protocols (Sambrook et al., 1989). The identities of the cloned fragments were confirmed by using a dideoxynucleotide sequencing kit (Amersham, Arlington Heights, IL).

Single-stranded $\left[{ }^{35} \mathrm{~S}\right]$-UTP-labeled cRNA probes were transcribed from plasmid vectors linearized downstream of the inserted cDNA fragment using either T7 or SP6 RNA polymerase (Promega, Madison, WI). Probes were purified over G-50 Sephadex spin columns (BoehringerMannheim, Indianapolis, IN), and their integrity was verified by electrophoresis on 5\% sequencing gels. The specificity of the probes was checked by Northern hybridization of blots containing $5 \mu \mathrm{g}$ of poly $\left(\mathrm{A}^{+}\right)$ mRNA isolated from adult mouse liver tissue.

Northern hybridization. Total RNA was isolated from tissues using the RNAzol B method, as described by the manufacturer (Tel-Test, Friendswood, TX). Poly $\left(\mathrm{A}^{+}\right)$RNA was isolated from the total RNA using oligo-dT cellulose columns, as described by the manufacturer (Molecular Research Center, Cincinnati, OH). The RNA was fractionated on $1 \%$ agarose $-2.2 \mathrm{M}$ formaldehyde gels and transferred by capillary action to $\zeta$-probe membrane. The blots were cross-linked by UV irradiation and prehybridized in in situ hybridization buffer (Friedman and Seeds, 1994) at $65^{\circ} \mathrm{C}$ for $15 \mathrm{~min}$. Heat-denatured cRNA probe was then added to a final concentration of $5 \times 10^{6} \mathrm{cpm} / \mathrm{ml}$, and hybridization performed for $16 \mathrm{hr}$ at $62^{\circ} \mathrm{C}$. The blots were then washed in descending concentrations of SSC $(2 \times, 1 \times, 0.5 \times, 0.1 \times)$ containing $1 \mathrm{~mm}$ DTT. The first three washes were conducted at room temperature, and the final wash was conducted at $65^{\circ} \mathrm{C}$. The blots were then exposed for $48 \mathrm{hr}$ to x-ray film with an intensifying screen at $-70^{\circ} \mathrm{C}$.

In situ hybridization. Frozen tissues were embedded in O.C.T. compound (Miles, Elkhart, IN), and $16 \mu \mathrm{m}$ cryostat sections were thawmounted onto 3-amino-propyltriethoxysilane-coated slides. In situ hybridization was performed as described by Friedman and Seeds (1994) with the following after modifications: the hybridization mixture contained $5 \times 10^{6} \mathrm{cpm} / \mathrm{ml}$ of cRNA probe, and the slides were hybridized at $62^{\circ} \mathrm{C}$ for $16 \mathrm{hr}$. The slides were washed a second time in $0.1 \times$ SSC for $15 \mathrm{~min}$ at $65^{\circ} \mathrm{C}$, and, after dipping in Kodak NTB-2 emulsion, the slides were stored in a dark box at $4^{\circ} \mathrm{C}$ for $28-35 \mathrm{~d}$.

Zymography. Extracts were prepared from freshly dissected tissue using a Dounce homogenizer and $5 \mathrm{vol}$ of $50 \mathrm{~mm}$ Tris- $\mathrm{HCl}, \mathrm{pH} 6.8$, containing $0.1 \%$ SDS, and aliquots were frozen at $-70^{\circ} \mathrm{C}$ until use. The protein concentration of the extracts was determined using a BCA protein assay (Pierce, Rockford, IL) with BSA as the standard. Aliquots of the extract were mixed with nonreducing $4 \times$ Laemmli sample buffer (Laemmli, 1970) and heated at $85^{\circ} \mathrm{C}$ for $10 \mathrm{~min}$ before being subjected to electrophoresis on standard $10 \%$ polyacrylamide gels containing $1 \mathrm{mg} / \mathrm{ml}$ casein and $0.1 \mathrm{U} / \mathrm{ml}$ plasminogen (Chromogenix, Molndal, Sweden). Control gels were run in the absence of plasminogen. Bands of caseinolytic activity were visualized by staining with $0.25 \%$ Coomassie brilliant blue R250 in 50\% methanol/10\% acetic acid and briefly destaining in the same solvent. The concentration of PA activity was estimated by scanning the gel on a computing densitometer using ImageQuant software (Molecular Dynamics, Sunnyvale, CA).

Cleavage of exogenous $H G F / S F$. Olfactory bulb extracts were prepared by homogenizing freshly dissected olfactory bulb tissue from adult mice in an ice-cold solution of $25 \mathrm{~mm}$ sucrose, $5 \mathrm{~mm}$ HEPES, pH 6.8, and aliquots were snap-frozen and stored at $-70^{\circ} \mathrm{C}$ until use. Protein concentration of the extract was determined as described above for zymography.

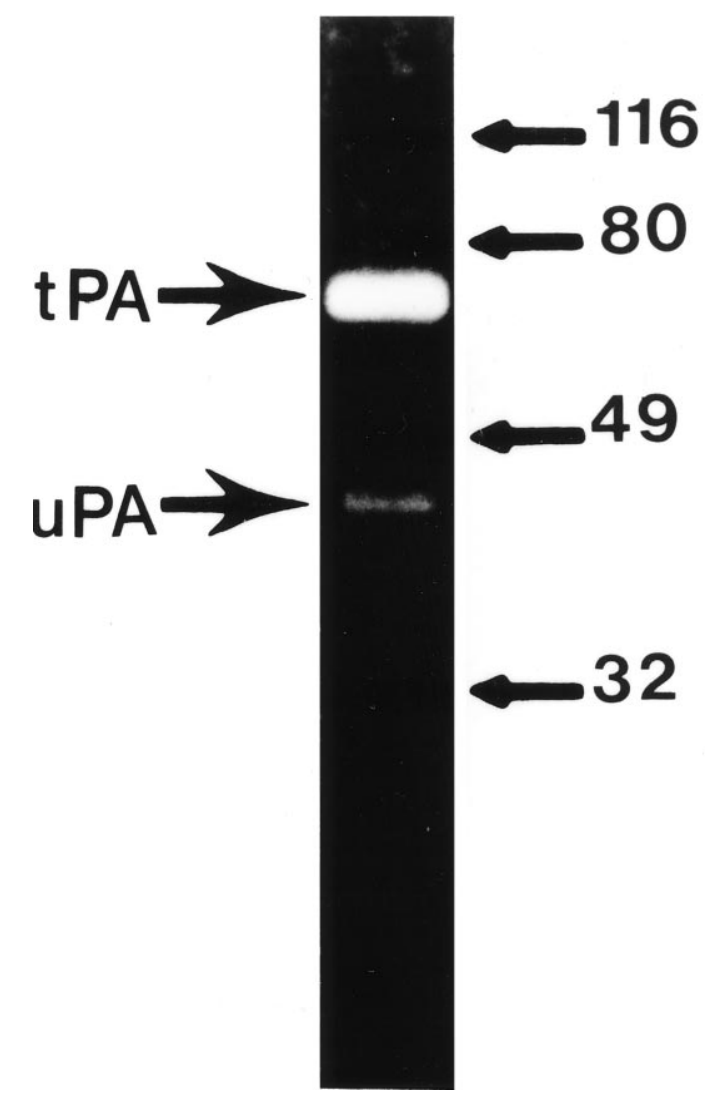

Figure 1. Zymographic analysis of the PA activity present in adult olfactory bulb extract. One microgram of total protein extract obtained from an adult olfactory bulb was subjected to zymographic analysis. The bands of caseinolytic activity corresponding to tPA $\left(M_{\mathrm{r}}=65,000\right)$ and uPA $\left(M_{\mathrm{r}}=\right.$ $37,000)$ activity are indicated on the left.

A predominately single-chain preparation containing $0.25 \mu \mathrm{g}$ of recombinant human proHGF/SF ( $\mathrm{R} \& \mathrm{D}$ Systems, Minneapolis, MN) was iodinated using Iodobeads per the manufacturer's instructions (Pierce, Rockford, IL) and purified by gel filtration over a Sephadex G-25 column. Approximately $4 \mathrm{ng}$ of iodinated proHGF/SF was incubated with $10 \mu \mathrm{g}$ of extract at $37^{\circ} \mathrm{C}$ for various periods of time $(0.5-3 \mathrm{hr})$ in siliconized tubes. Before the addition of iodinated proHGF/SF, the extracts were incubated on ice for 30 min with $0.2 \mu \mathrm{g}$ of antibodies against murine tPA (American Diagnostic, Greenwich, CT) or an equivalent amount of a nonspecific (rabbit anti-goat $\mathrm{IgG}$ ) $\mathrm{IgG}$ fraction as control. The reactions were stopped by adding an equal volume of $2 \times$ reducing SDS-PAGE loading buffer (Laemmli, 1970) and heating at $85^{\circ} \mathrm{C}$ for $10 \mathrm{~min}$. Samples were then analyzed by $10 \%$ SDS-PAGE and the bands visualized by autoradiography. For quantification, the dried gels were exposed to a phosphorimager screen (Molecular Dynamics) for $16 \mathrm{hr}$.

\section{RESULTS}

Although tPA has been shown to be the primary PA expressed in other regions of the brain (Seeds et al., 1992; Sappino et al., 1993), there has been no clear identification of the PA activity expressed in the olfactory bulb. However, both tPA and uPA mRNA were seen (Dent et al., 1993) in the rat olfactory bulb. Because both tPA and UPA are capable of activating $\mathrm{HGF} / \mathrm{SF}$, we wished to identify directly the PA activity present in the mouse olfactory bulb. Zymographic analysis revealed primarily tPA $\left(M_{\mathrm{r}}=65,000\right)$ and a small amount of uPA $\left(M_{\mathrm{r}}=37,000\right)$ activity present in olfactory bulb extract (Fig. 1). Quantitative densitometric analysis of the zymographs showed that tPA constituted $>94 \%$ of the total PA activity present in the extract. All of the caseinolytic activity observed in the gels was plasminogen-dependent, and no other 


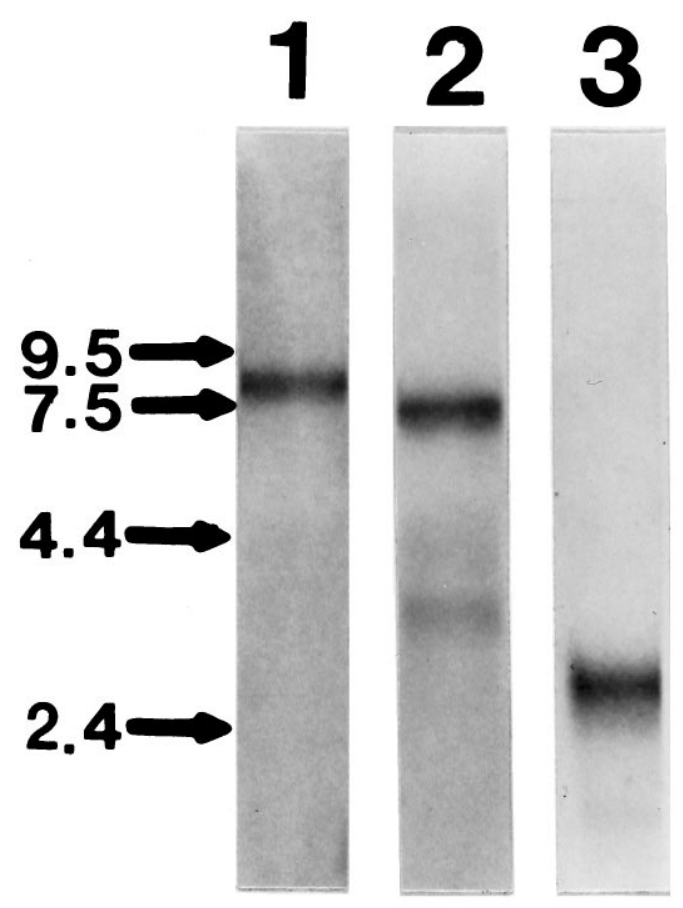

Figure 2. Northern blot analysis of HGF/SF, c-met, and tPA mRNA expression in adult olfactory bulb. Blots containing $5 \mu \mathrm{g}$ of poly $\left(\mathrm{A}^{+}\right) \mathrm{RNA}$ prepared from the adult olfactory bulbs were hybridized with ${ }^{35} \mathrm{~S}$-labeled cRNA antisense cRNA probes to c-met, $\mathrm{HGF} / \mathrm{SF}$, and tPA (lanes 1-3, respectively). The size of RNA standards is as indicated on the left in $\mathrm{kb}$.

proteolytic activity was detected on the gels. Thus, as in other regions of the mouse brain, tPA represents the majority of PA activity present in murine olfactory bulb.

To better characterize their expression in the olfactory system, partial murine $\mathrm{HGF} / \mathrm{SF}$ and $c$-met cDNA clones were prepared by RT-PCR of total liver RNA and used to generate probes for Northern blot and in situ hybridization analysis. Northern blot analysis revealed that both $\mathrm{HGF} / \mathrm{SF}$ and $c$-met mRNA were expressed in the adult olfactory bulb (Fig. 2). The $\mathrm{HGF} / \mathrm{SF}$ cRNA probe hybridized to a $6.0 \mathrm{~kb}$ transcript and a $3.0 \mathrm{~kb}$ transcript, whereas the $c$-met $\mathrm{cRNA}$ probe detected an $8.5 \mathrm{~kb}$ transcript. These correspond to the major HGF/SF and c-met transcripts present in other murine tissues (Chan et al., 1988; Lee et al., 1993). In addition, a tPA cRNA probe hybridized to a $2.8 \mathrm{~kb}$ transcript corresponding to the major tPA transcript in murine brain (Sappino et al., 1993; Friedman and Seeds, 1995). These results reveal that HGF/SF, $c$-met, and tPA mRNA all are expressed in the adult murine olfactory bulb and demonstrate the specificity of the probes for their target mRNA.

In situ hybridization was performed on mouse embryos of various ages using cRNA probes to $\mathrm{HGF} / \mathrm{SF}, c$-met, and tPA mRNA to determine which olfactory structures express each mRNA. In mice, the characteristic organization of the $\mathrm{OC}$ and the distribution of cell types in the olfactory epithelium becomes apparent around embryonic day 12 (E12) (Cuschieri and Bannister, 1975; Noda and Harada, 1981). In the developing OC, transcripts of all three mRNAs were detectable at E14, the earliest age examined. At this time, $c$-met expression was limited to the olfactory neuroepithelium close to the luminal surface, whereas HGF/SF expression was observed in the adjacent olfactory mucosa (OM) (Figs. 3, 4). Figure 3 shows tPA mRNA expression throughout the olfactory neuroepithelium, including the portion of the epithelium that expresses $c$-met mRNA. The hybridization of the antisense cRNA probes was specific as revealed by the absence of hybridization to these structures with control sense cRNA probes (Fig. 3). This pattern of expression was observed throughout development of the $\mathrm{OC}$ with the highest levels of all three transcripts being observed during the period from E14 to E17. Expression of all three transcripts in the OC was detected at lower levels postnatally (see Fig. 8) (data not shown); however, only tissues up to postnatal day 4 (P4) were examined. These results demonstrate the relatively coordinate expression of tPA, $c$-met, and HGF/SF mRNA in the developing OC.

At E14, the development of the olfactory bulb is evident by an outpocketing at the anterior end of the lateral ventricle (LV). Several distinct layers are recognizable in the E14 bulb including the subventricular zone (SVZ), the marginal zone (MZ), and the olfactory nerve fiber layer (ONL) (Hinds, 1968). At this time, a low level of HGF/SF expression was observed in the SVZ at the anterior end of the LV (Fig. 3). Expression of HGF/SF in the MZ and ONL was at low or background levels. Neither $c$-met nor tPA hybridization was evident in any layer of the primordial olfactory bulb (Fig. 3).

By E16, the definitive mitral cell layer (MCL) of the olfactory bulb can be distinguished, and the SVZ has increased in size (Hinds, 1968). At this age, c-met expression was detected in the MCL and in the MZ just superficial to the developing MCL (Figs. $5,6)$. Expression of $c$-met was not above background levels in any other area of the E16 bulb. Meanwhile, the expression of HGF/SF had increased throughout the SVZ of both the olfactory and LVs (Fig. 5). Hybridization of $\mathrm{HGF} / \mathrm{SF}$ outside of the SVZ remained at or below background levels.

By E18, the characteristic organization of the adult olfactory bulb can be distinguished, including the ONL, MCL, internal plexiform layer (IPL), external plexiform layer (EPL), granule cell layer (GCL), and even a few glomeruli (Hinds, 1968). At this time, expression of $c$-met was clearly detected in the MCL (Figs. 7); by contrast, the cells in the SVZ and the developing GCL showed little $c$-met hybridization. Low levels of $\mathrm{HGF} / \mathrm{SF}$ expression were observed just below the MCL in the developing GCL of the olfactory bulb. Higher levels of $\mathrm{HGF} / \mathrm{SF}$ expression were observed in the SVZ lining the LVs and olfactory ventricles (OVs) including the region of the SVZ, which extends from the anterior portion of the LV into the olfactory bulb (Fig. 7). This portion of the SVZ serves as a pathway for migrating olfactory interneuron precursors and is often referred to as the rostral migratory stream (RMS) (Lois and Alvarez-Buylla, 1994). Figure 7 demonstrates that tPA was also expressed throughout the SVZ and RMS, coincident with the expression of HGF/SF. Consistent with previous studies (Friedman and Seeds, 1994), a high level of tPA expression was also observed in the meninges (M) surrounding the olfactory bulb and neocortex.

Expression of $\mathrm{HGF} / \mathrm{SF}$ in the RMS continued during postnatal development, reaching a peak at $\sim$ P8 before declining in adulthood (Fig. 8). Expression of HGF/SF above background levels was not observed outside of the SVZ. During this period, c-met expression continued in the MCL and could be observed in the anterior olfactory nucleus (AON) (Fig. 8). The expression of tPA mRNA was observed in the AON concurrent with the expression of $c$-met mRNA, as well as in the ONL and the dorsal part of the GCL surrounding the SVZ of the P8 bulb.

The adult olfactory bulb consists of the six distinct layers: the ONL, glomerular layer (GL), EPL, IPL, MCL, and GCL. In the 

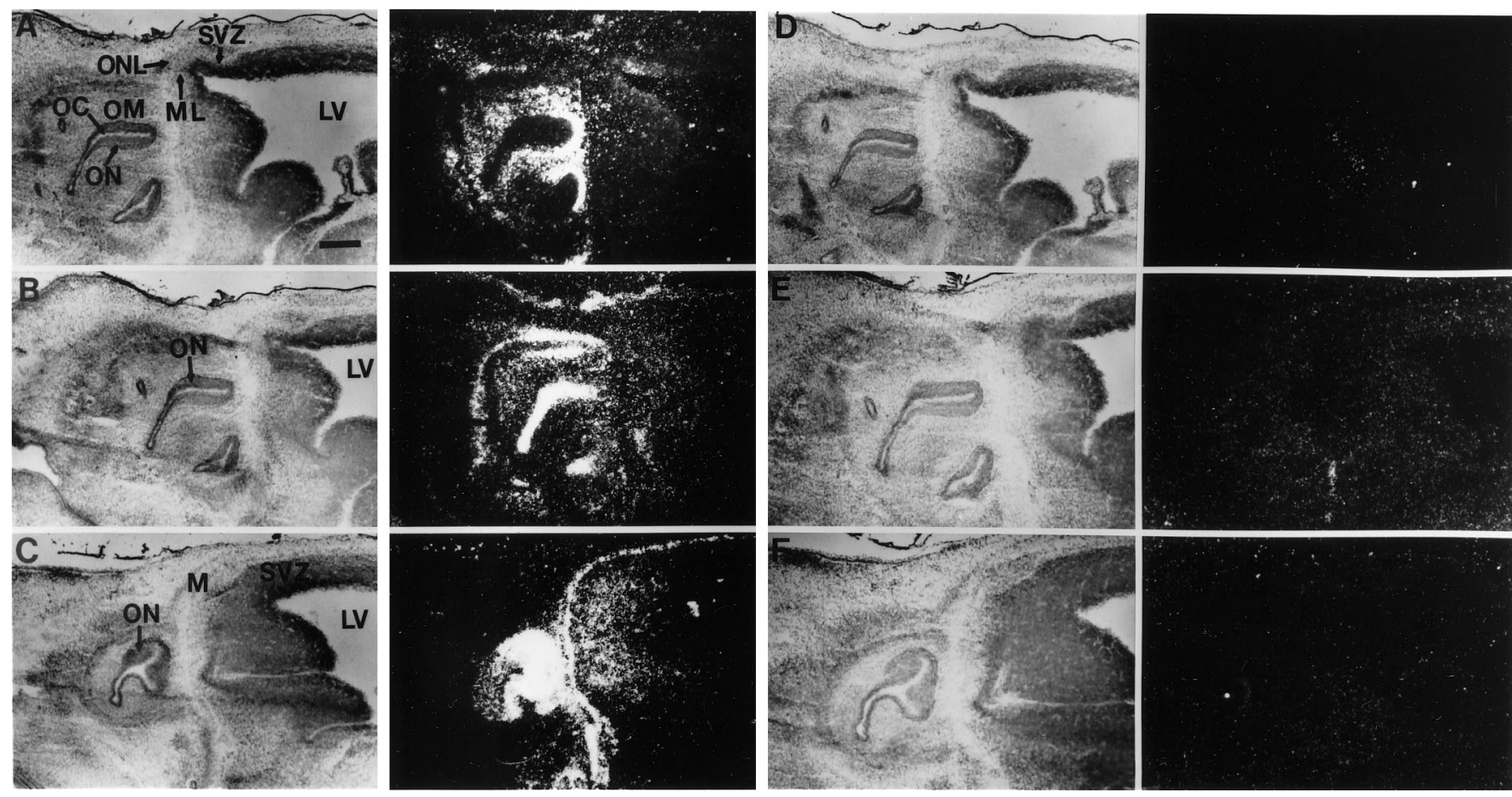

Figure 3. Expression of HGF/SF, c-met, and tPA in the developing E14 olfactory system. The left panels are bright-field images, and the right panels are corresponding dark-field images. Hybridization of ${ }^{35} \mathrm{~S}$-labeled antisense cRNA probes with E14 sagittal sections. $A$, Expression of $\mathrm{HGF} / \mathrm{SF}$ is high in the $\mathrm{OM}$ of the OC. Lower expression is also observed in the ventricular zone at the anterior end of the LV, which will develop into the olfactory bulb. $B$, Expression of $c$-met is observed in the olfactory neuroepithelium lining the OC. $C$, High-level expression of tPA is observed throughout the olfactory neuroepithelium. Use of ${ }^{35} \mathrm{~S}$-labeled sense $\mathrm{HGF} / \mathrm{SF}, c-m e t$, and tPA $(D-F$, respectively) cRNA probes detects no specific hybridization. Scale bar, $310 \mu \mathrm{m}$. $A O N$, Anterior olfactory nucleus; $D O N$, dorsal anterior olfactory nucleus; $E P L$, external plexiform layer; $G L$, also $g$ (Fig. 9), glomerular layer; $G C L$, granule cell layer; $I P L$, internal plexiform layer; $L O N$, lateral anterior olfactory nucleus; $L V$, lateral ventricle; $M$, meninges; $M C L$, also $M L$ (Fig. 3 ), mitral cell layer; $M Z$, marginal zone; $O C$, olfactory canal; $O M$, olfactory mucosa; $O N$, olfactory neuroepithelium; $O N L$, olfactory nerve fiber layer; $O V$, olfactory ventricle; $R M S$, rostral migratory stream; $S V Z$, subventricular zone.

adult olfactory bulb, expression of $\mathrm{HGF} / \mathrm{SF}$ was restricted to the cells surrounding the glomeruli. These cells appear to be periglomerular neurons (Fig. 9). c-met mRNA was clearly detected in the MCL and ONL (possibly Schwann cells that ensheathe the olfactory nerve fibers) (Fig. 9). Cells in the ONL exhibited a high level expression of tPA mRNA, whereas cells in the MCL and GCL expressed a somewhat lower level of tPA mRNA (Fig. 9). Thus, in the adult olfactory bulb, tPA appears to be expressed in close proximity to $\mathrm{HGF} / \mathrm{SF}$-expressing periglomerular neurons onto which $c$-met-expressing mitral cells synapse. This raises the possibility that $\mathrm{PA}$ may activate $\mathrm{HGF} / \mathrm{SF}$ produced by periglomerular cells, which would then produce a physiological response from the c-met-expressing mitral cells, the dendrites of which project into the glomeruli.

The results from the in situ hybridization study indicate that the expression of tPA is relatively coincident with the expression of either $\mathrm{HGF} / \mathrm{SF}$ or its receptor $c$-met during the development of some structures of the olfactory system, strengthening a possible role for $\mathrm{tPA}$ as an activator of $\mathrm{HGF} / \mathrm{SF}$ in the olfactory system. To determine whether the tPA present in the olfactory bulb could actually cleave proHGF/SF, an iodinated preparation of predominantly single-chain $\mathrm{HGF} / \mathrm{SF}$ (scHGF/SF) was incubated with olfactory bulb homogenates. When subjected to reducing SDSPAGE analysis, the iodinated $\mathrm{scHGF} / \mathrm{SF}$ produced a major band of $\sim 92 \mathrm{kd}$ as well as minor bands of $62 \mathrm{kd}$ and 32-34 kd (Fig. $10 A$ ). Previous studies have shown that the $92 \mathrm{kd}$ band represents the $\mathrm{scHGF} / \mathrm{SF}$, which is cleaved to form the heavy $(62 \mathrm{kd})$ and light (32-34 kd) chains of the active HGF/SF heterodimer (Gak et al., 1992; Naka et al., 1992). We reasoned that if olfactory bulb extract contained an activator of $\mathrm{HGF} / \mathrm{SF}$, the cleavage of scHGF/SF should be accompanied by a decrease in the $92 \mathrm{kd}$ band, and if this activator were tPA, then the decrease should be inhibited by antibodies that neutralize tPA. Figure 10 demonstrates that incubation of iodinated scHGF/SF with adult olfactory bulb homogenate produced a decrease in the amount of the $92 \mathrm{kd}$ band. A similar result was obtained using olfactory bulb homogenates obtained from mice of various postnatal ages and occurred in a concentration- and time-dependent manner (data not shown). We did not observe a concomitant increase in the intensity of the heavy and light chains, probably because of nonspecific proteolysis. Other researchers have noted a similar susceptibility of the heavy and light chains to degradation even when using purified preparations of tPA and uPA (Mars et al., 1993). Using an amount of olfactory bulb homogenate that resulted in an $\sim 50 \%$ decrease in the $92 \mathrm{kd}$ band, preincubation of the homogenate with tPA antibodies greatly inhibited the cleavage of the $92 \mathrm{kd}$ proHGF/SF (Fig. 10B). This inhibition was specific, because preincubation of the homogenate with a like amount of a control IgG was without effect. The inclusion of the plasmin inhibitor aprotinin in the assay had no effect on the decrease of the $92 \mathrm{kd}$ band or on the ability of the tPA antibodies to inhibit the decrease (data not shown). This indicates that the decrease in the $92 \mathrm{kd}$ band was not attributable to plasmin in the homogenate and that the observed inhibition by the tPA antibodies was a direct effect on a tPA cleavage and not attributable to inhibition of tPA-mediated conversion of plasminogen to plasmin. Furthermore, preincuba- 

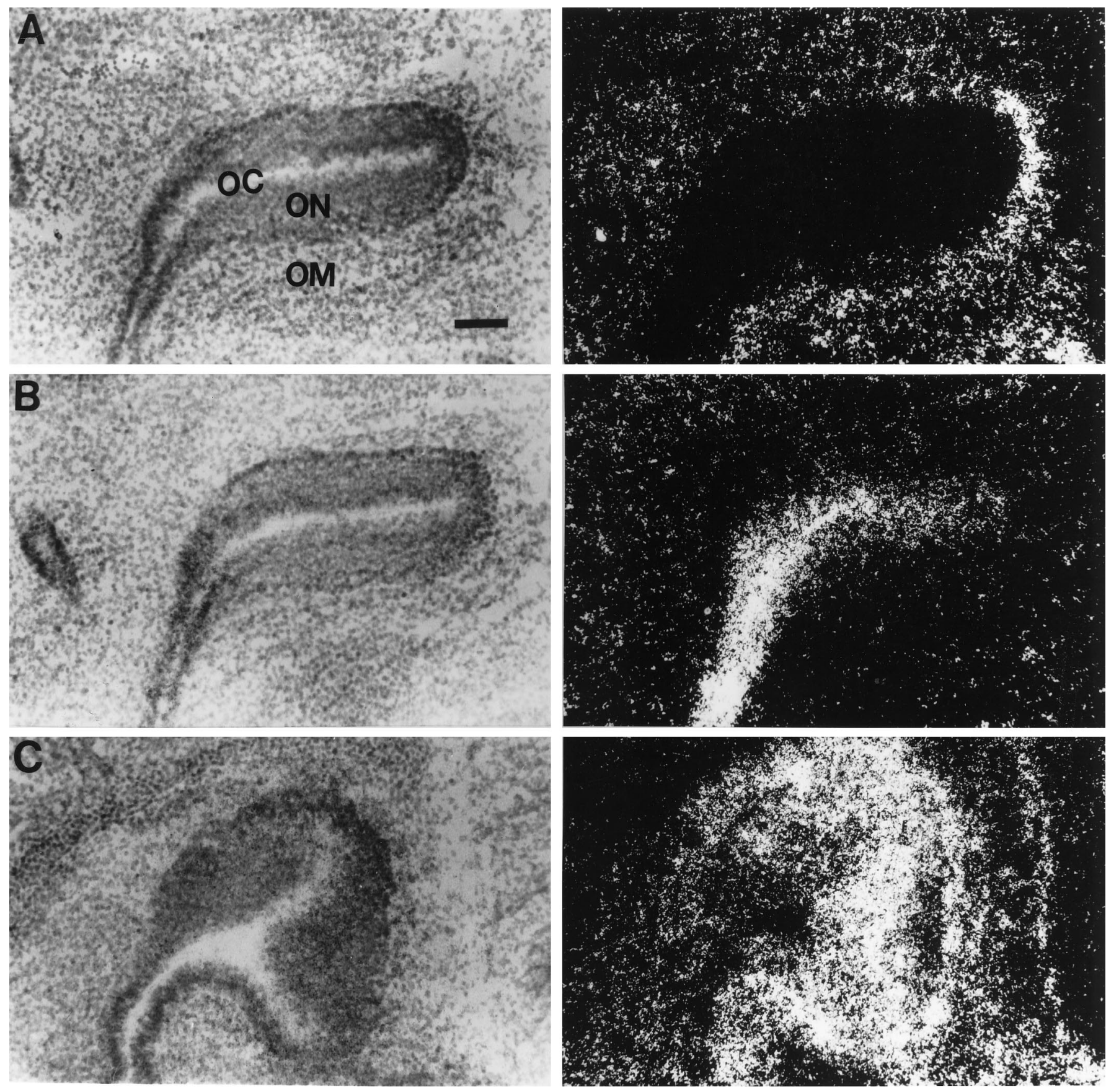

Figure 4. Higher-power photomicrograph of the developing OC shown in Figure 3. The left panels are bright-field images, and the right panels are corresponding dark-field images. $A$, Expression of HGF/SF is detected in the OM underlying the olfactory neuroepithelium. $B$, Expression of $c$-met is confined to the portion of the olfactory neuroepithelium lining the OC. $C$, Expression of tPA is observed throughout the olfactory neuroepithelium. Scale bar, $80 \mu \mathrm{m}$. See legend to Figure 3 for abbreviations.

tion with the uPA inhibitor amiloride was also without effect, indicating that the observed proHGF/SF cleavage was not attributable to the minor amount of uPA activity present in the homogenate (data not shown). These results demonstrate that tPA present in the olfactory bulb extract represents the primary exogenous proHGF/SF cleaving activity. Together with the relatively coincident expression of HGF/SF, $c$-met, and tPA mRNAs, these results strongly suggest that tPA functions in vivo as an activator of $\mathrm{HGF} / \mathrm{SF}$ in the murine olfactory system.

\section{DISCUSSION}

In this study, we demonstrate that the expression of tPA mRNA was relatively coincident with $c$-met mRNA and, in some instances, with HGF/SF mRNA during development of the OC and bulb. In the developing OC, both tPA mRNA and c-met mRNA were expressed in the olfactory neuroepithelium, whereas $\mathrm{HGF} / \mathrm{SF}$ mRNA was expressed in the adjacent OM. These results extend the earlier preliminary demonstration of $\mathrm{HGF} / \mathrm{SF}$ and c-met mRNA expression (Sonnenberg et al., 1993) and of tPA 

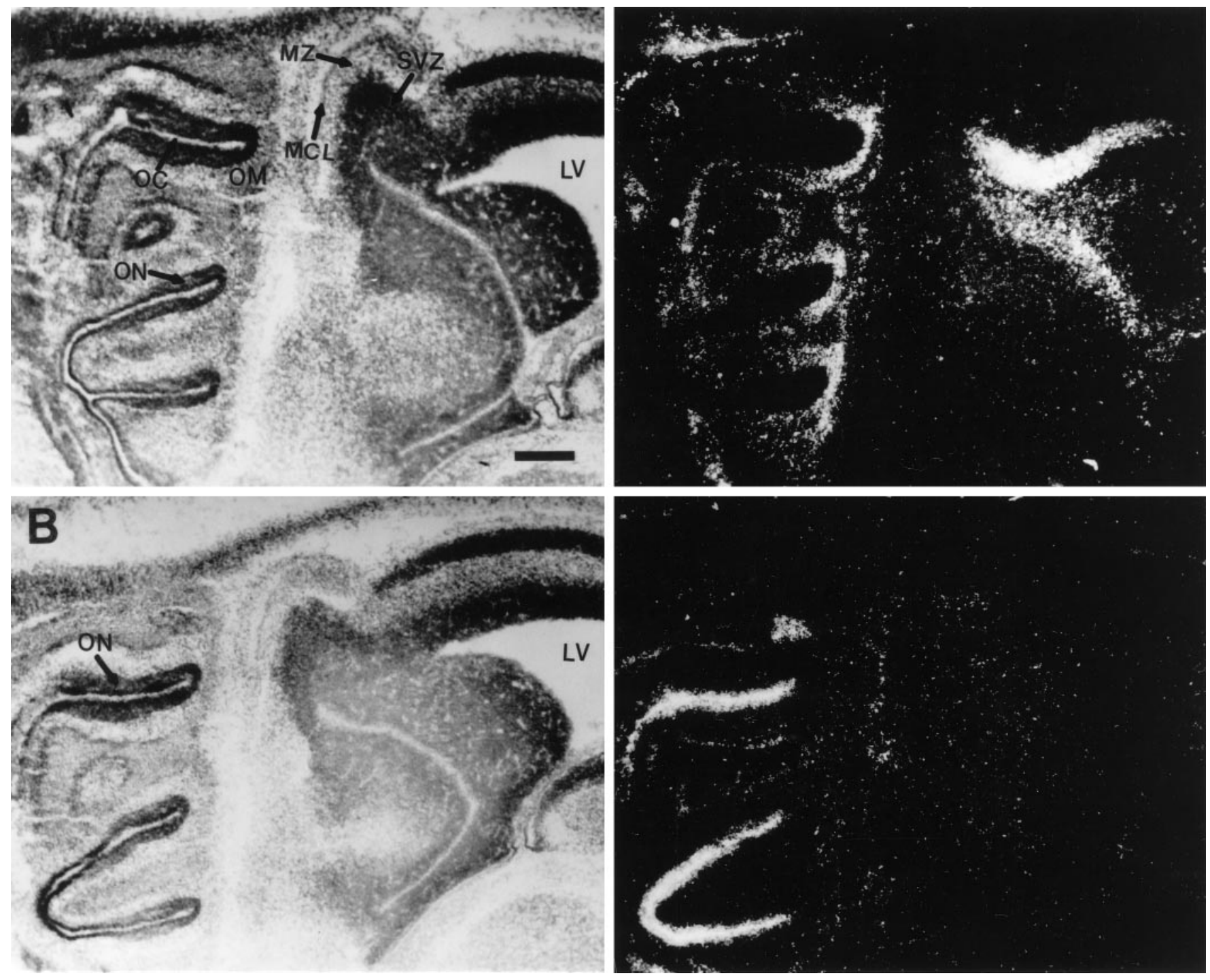

Figure 5. Expression of HGF/SF and c-met in the developing olfactory system at E16. The left panels are bright-field images, and the right panels are corresponding dark-field images. Hybridization of ${ }^{35} \mathrm{~S}$-labeled antisense cRNA probes with E16 sagittal sections. $A$, Expression of HGF/SF is observed in the OM and in the SVZ of the primordial olfactory bulb. $B$, Expression of $c$-met at the luminal surface of the olfactory neuroepithelium and in the MCL of the olfactory bulb. Scale bar, $300 \mu \mathrm{m}$. See legend to Figure 3 for abbreviations.

mRNA expression (Friedman and Seeds, 1994) in the developing $\mathrm{OC}$ to demonstrate the concurrent expression of $\mathrm{HGF} / \mathrm{SF}$ and $c$-met mRNA with tPA. We also observed the expression of $\mathrm{HGF} / \mathrm{SF}$ and $c$-met mRNA in the developing and adult olfactory bulb and demonstrate the relatively coincident expression of tPA mRNA within this structure. Furthermore, tPA was found to be the predominant PA activity present in olfactory bulb extracts and to be responsible for the majority of exogenous $\mathrm{proHGF} / \mathrm{SF}$ cleaving activity in these extracts. These results indicate that HGF/SF may play an important role in the adult and developing murine olfactory system were tPA may be localized near $c$-met receptors to generate the active, but relatively unstable, HGF/SF in the immediate vicinity of its receptor.

In mice, development of the olfactory epithelium begins at $\sim$ E9 and continues throughout gestation (Hinds, 1968). The expression of $\mathrm{HGF} / \mathrm{SF}, c$-met, and tPA mRNA were detectable at the earliest time investigated (E14), and levels of all three mRNAs were high through E18 (Figs. 3-7). E11-E18 is a period of extensive tissue remodeling and cell migration, as well as the time of greatest olfactory sensory neuron differentiation, axonal outgrowth, and synaptogenesis in the olfactory bulb (Brunjes and Frazier, 1986; Farbman, 1991). tPA may have several functions during this developmental period. The proteolytic activity of tPA may directly influence tissue remodeling and cell migration by degrading extracellular matrix and cell adhesion molecules, as has been proposed previously (Seeds et al., 1980, 1990; Krystosek and Seeds, 1981; Moonen et al., 1982; Pittman 1985). In addition, tPA may also participate in a signaling cascade regulating the activity of $\mathrm{HGF} / \mathrm{SF}$ and possibly the proliferation, differentiation, and migration of cells in the developing OC. The expression of tPA in other neuronal tissues that do not express $\mathrm{HGF} / \mathrm{SF}$ or $c$-met suggests tPA may have other functions in these structures, perhaps activating other latent growth factors, cytokines, chemokines, and other neuropeptides.

The fact that HGF/SF is secreted into the extracellular matrix as an inactive prohormone implies that cleavage to the active form may be a highly regulated step. If tPA serves as an activator of $\mathrm{HGF} / \mathrm{SF}$ in vivo, control of HGF/SF activity could be achieved by 

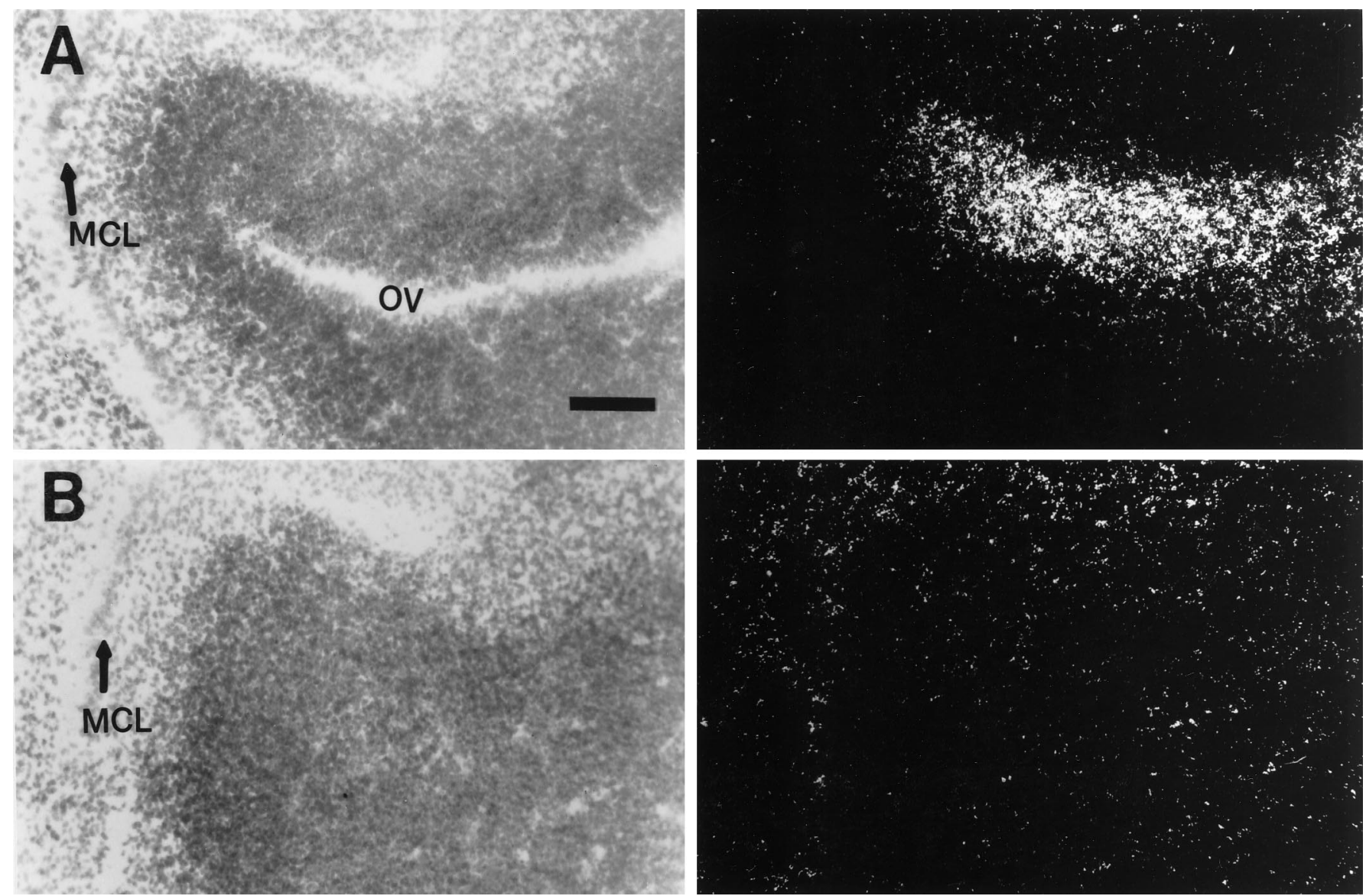

Figure 6. Higher-power photomicrograph of HGF/SF and c-met expression in the developing E16 olfactory bulb shown in Figure 5. The left panels are bright-field images, and the right panels are corresponding dark-field images. Hybridization of ${ }^{35} \mathrm{~S}$-labeled antisense cRNA probes with E16 sagittal sections. $A$, Expression of HGF/SF is high in the SVZ of the primordial bulb. B, Expression of $c$-met can be seen in the developing MCL. Scale bar, $100 \mu \mathrm{m}$. See legend to Figure 3 for abbreviations.

maintaining a strict balance between tPA and the various matrix molecules that can influence its activity. Regulators of tPA activity that are known to be expressed in the developing murine olfactory system include thrombospondin, an enhancer of tPA activity (O'Shea and Dixit, 1988), and protease nexin-1, an inhibitor of tPA (Mansuy et al., 1993).

The recent observation that $c$-met expression is essential for myoblast migration and that myoblasts appear to migrate up a concentration gradient of $\mathrm{HGF} / \mathrm{SF}$ (Bladt et al., 1995) suggests that $\mathrm{HGF} / \mathrm{SF}$ may play a similar role in the development of the olfactory system. During development of the olfactory system, $\mathrm{HGF} / \mathrm{SF}$ may act as a chemoattractant for migrating cells and neurites expressing $c$-met. The growth cones of some neurons are known to express a high-affinity receptor for tPA (Verrall and Seeds, 1989; Seeds et al., 1990, 1992). The binding of tPA to a receptor on the surface of migrating cells and/or growth cones expressing $c$-met would provide localized activation of $\mathrm{HGF} / \mathrm{SF}$ in the immediate vicinity of $c$-met when the cell/growth cone enters a region expressing proHGF/SF. The observed susceptibility of the heterodimeric form of $\mathrm{HGF} / \mathrm{SF}$ to nonspecific degradation in vitro may indicate a rapid turnover of the active form in vivo and the importance of such a localized activation mechanism. One area where such a mechanism may function is the developing embryonic OC. Here, high levels of HGF/SF, c-met, and tPA mRNA are expressed at E14 through E19, which is a period of intense cell migration and axonal growth from the neuroepithe- lium to the developing olfactory bulb (Farbman, 1991). HGF/SF produced in the mucosa may act as a chemoattractant for axonal growth cones of olfactory receptors and/or the migrating epithelial cells that precede the axons out of the epithelium. Once in the mucosa, migrating cells/growth cones may use additional guidance cues for continued migration to the bulb. Although not investigated in mature animals, all three mRNAs were expressed in OC $\mathrm{P} 4$, the oldest age examined. If this pattern of expression continues in adult animals, it may reflect a continued role for $\mathrm{HGF} / \mathrm{SF}$ and $c$-met in axonal guidance of newly generated olfactory sensory neurons that occurs throughout adulthood in mice (Graziadei and Monti-Graziadei, 1978).

Based on its expression patterns in other regions of the brain, $\mathrm{HGF} / \mathrm{SF}$ has been proposed to act as a target derived neurotrophic factor (Jung et al., 1994), and HGF/SF has been shown to promote the survival of motor and hippocampal neurons in culture (Honda et al., 1995; Wong et al., 1995). Within the olfactory bulb, the expression patterns of $\mathrm{HGF} / \mathrm{SF}$ and $c$-met suggest a neurotrophic role in the formation and/or maintenance of the olfactory glomeruli. HGF/SF expressed by the periglomerular cells may function in the formation and maintenance of synaptic connections among periglomerular dendrites, sensory neuron axons, and mitral cell dendrites, all of which form synapses within the glomeruli (Pinching and Powell, 1971; White, 1973; Hinds and Hinds, 1976). The observed upregulation of $c$-met mRNA in the MCL (Fig. 5) at an age (E15) when the first synaptic connections 

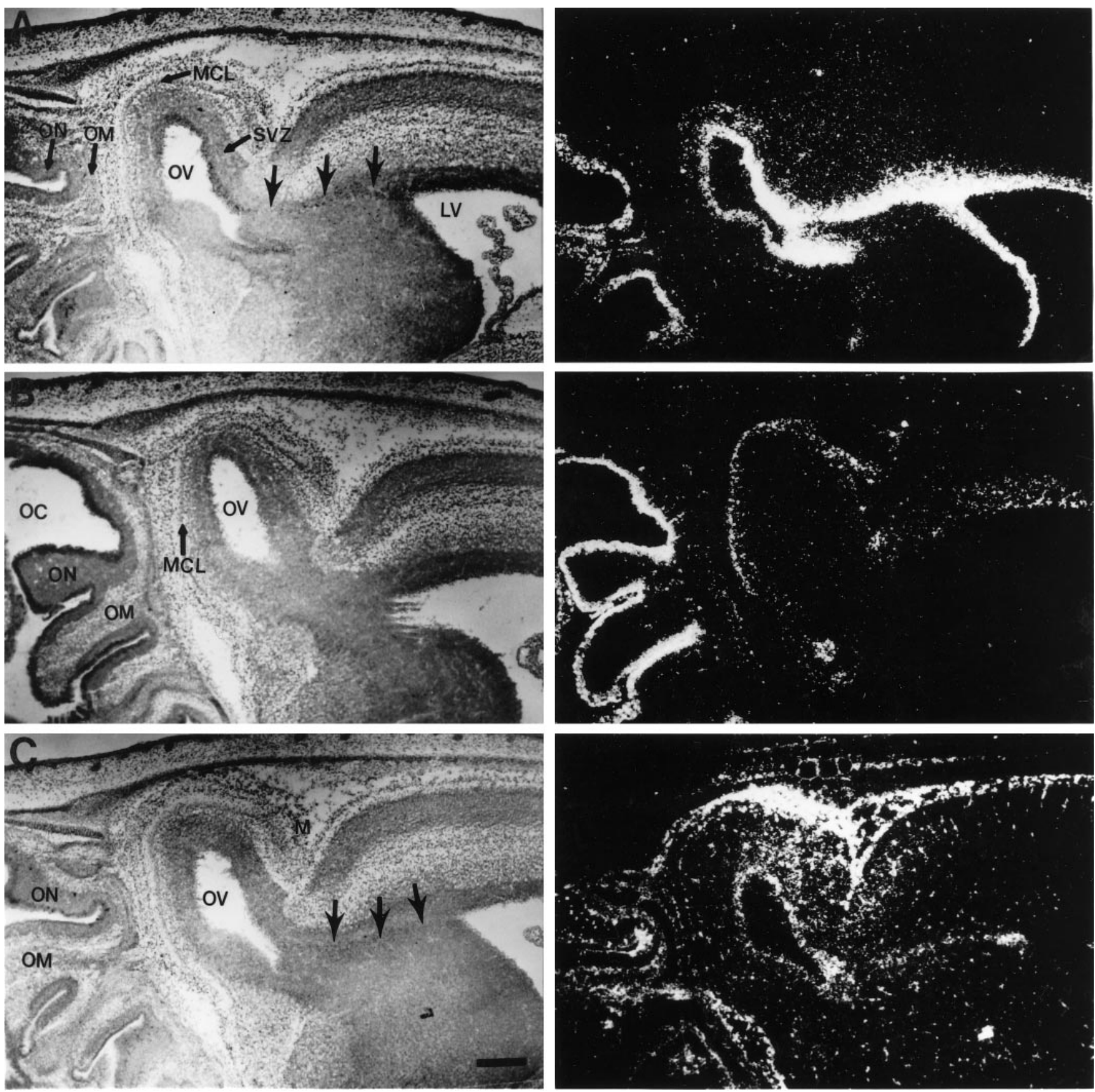

Figure 7. Expression of HGF/SF, c-met, and tPA in the developing olfactory system at E18. The left panels are bright-field images, and the right panels are corresponding dark-field images. Hybridization of ${ }^{35}$ S-labeled antisense cRNA probes with E18 sagittal sections. $A$, HGF/SF expression is observed in the OM of the developing nasal cavity. In the developing bulb, expression of HGF/SF is high in the SVZ of the LVs and OVs including the RMS (indicated by arrows) extending from the LV into the olfactory bulb. B, Expression of $c$-met occurs in the ON and MCL. $C$, Expression of tPA is high in the $\mathrm{M}$ and coincident with HGF/SF expression in the SVZ and RMS (indicated by arrows). Scale bar, $280 \mu \mathrm{m}$. See legend to Figure 3 for abbreviations.

in the olfactory bulb are observed supports this suggestion (Hinds and Hinds, 1976; Brunjes and Frazier, 1986). The continued expression of $c$-met mRNA in the MCL and ONL, and of HGF/SF mRNA by periglomerular cells in the adult bulb, suggests that $\mathrm{HGF} / \mathrm{SF}$ may continue to function in the maintenance of glomer- ular synapses and/or the formation of new synaptic connections resulting from the turnover of olfactory sensory neurons. Expression of tPA and c-met in the AON of postnatal mice is also observed (Fig. 8). Because centrifugal fibers from portions of the AON project to the periglomerular region of the olfactory bulb

Figure 8. Postnatal expression of HGF/SF, c-met, and tPA in the olfactory system. The left panels are bright-field images, and the right panels are corresponding dark-field images. Hybridization of ${ }^{35} \mathrm{~S}$-labeled antisense cRNA probes with postnatal sagittal sections. $A$, Expression of HGF/SF is observed in the RMS from the anterior lateral ventricle into the olfactory bulb at P0. $B$, Expression of HGF/SF in the RMS at P8. $C$, Expression of $c$-met in the P8 olfactory bulb is observed in the MCL and the AON. D, Expression of tPA in the P8 olfactory bulb. Scale bar, $255 \mu \mathrm{m}$. See legend to Figure 3 for abbreviations. 



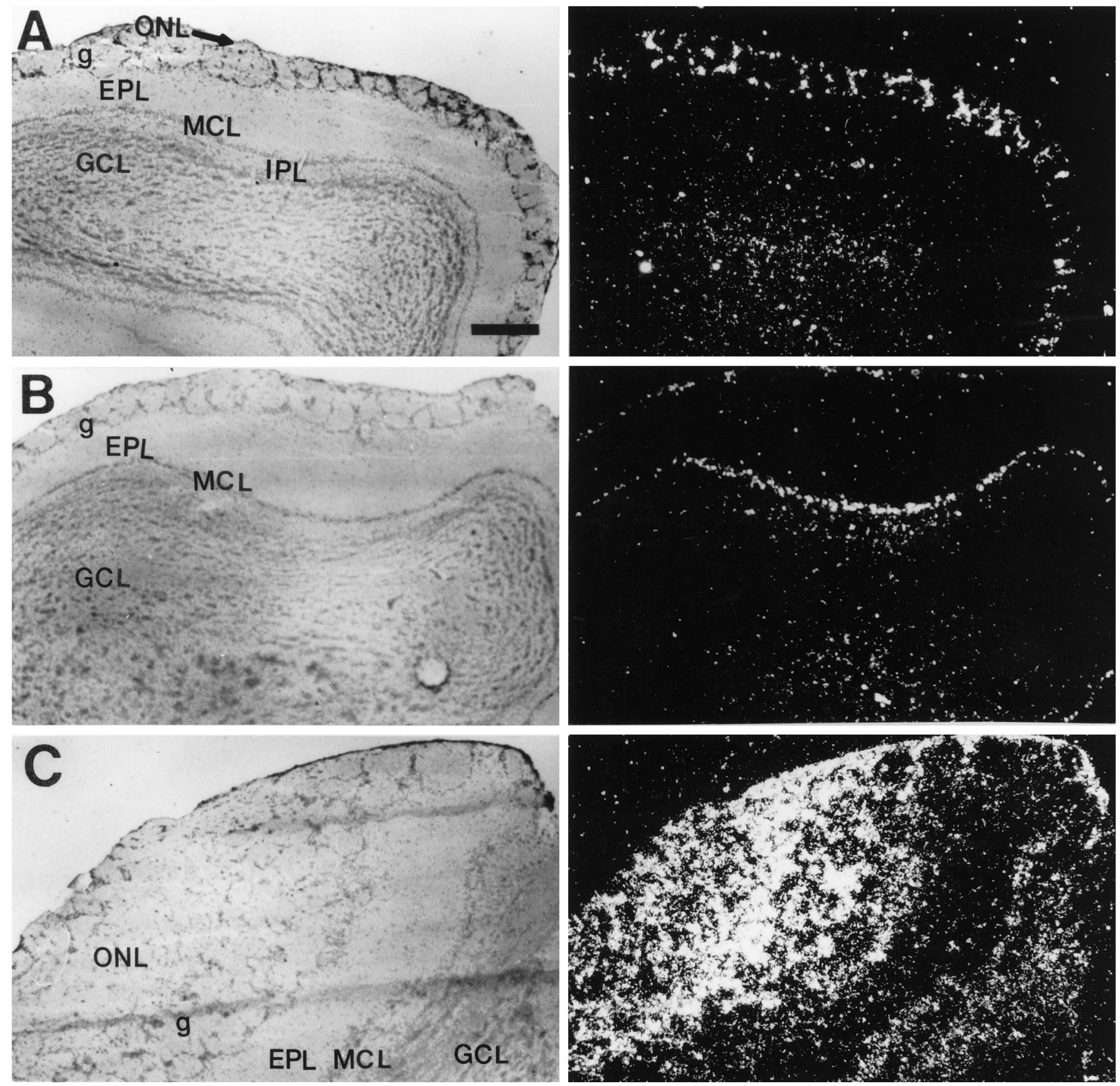

Figure 9. Expression of HGF/SF, c-met, and tPA in the adult olfactory bulb. The left panels are bright-field images, and the right panels are corresponding dark-field images. Hybridization of ${ }^{35} \mathrm{~S}$-labeled antisense cRNA probes with adult olfactory bulb sagittal sections. $A$, Expression of HGF/SF is restricted to the periglomerular cells in the GL. $B, c$-met expression is confined to the MCL and the ONL. C, Expression of tPA is high in the ONL and lower in the MCLs and GCLs. Scale bar, $255 \mu \mathrm{m}$. See legend to Figure 3 for abbreviations.

(Luskin and Price, 1983), periglomerular-derived HGF/SF may function as a target-derived neurotrophic factor for some neurons of the AON as well. In all cases, tPA was expressed by cells also expressing $c$-met, suggesting that tPA localized on the surface of these cells may activate $\mathrm{HGF} / \mathrm{SF}$.

An intriguing result was the observation of a low level of tPA expression coincident with HGF/SF expression in the SVZ and RMS (Fig. 7). This expression coincides with the peak time (E17-P7) of olfactory interneuron proliferation in the SVZ and the migration of these cells within the RMS (Hinds, 1968; Farbman, 1991). The SVZ, a discrete region at the anterior end of the $\mathrm{LV}$, continues to produce neuronal precursors well into the adult life of the mouse. These precursors migrate via the RMS to the olfactory bulb, where they differentiate into granule and periglomerular neurons (Corotto et al., 1993; Luskin, 1993; Lois and Alvarez-Buylla, 1994; Lois et al., 1996). These cells migrate strictly within the confines of the RMS toward the bulb without the aid of radial glial or axon fibers. The known motogenic and mitogenic activity of $\mathrm{HGF} / \mathrm{SF}$ on other cell types and the observed coexpression of HGF/SF and tPA in the RMS during the period of peak olfactory interneuron production suggest that $\mathrm{HGF} / \mathrm{SF}$ may be involved in the proliferation, migration, and/or differentiation of these precursors. 

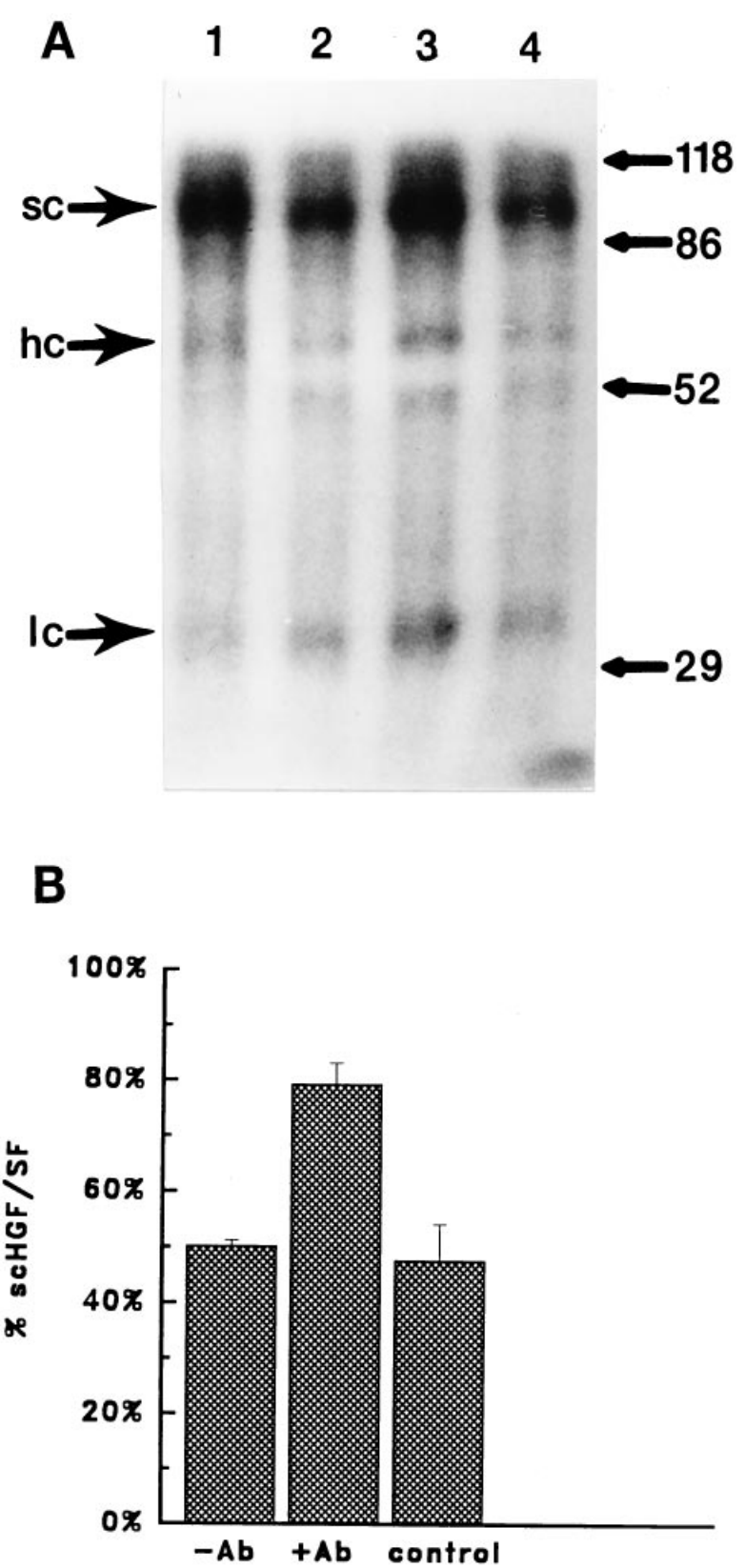

Figure 10. Cleavage of scHGF/SF by olfactory bulb extract is inhibited by preincubation with antibodies to tPA. Iodinated HGF/SF was subjected to treatment with olfactory bulb homogenate that had been preincubated with either polyclonal antibodies against murine tPA or a like amount of control $\operatorname{IgG}$ preparation. $A$, Autoradiogram showing inhibition of scHGF/SF cleavage by tPA antibodies. Lane 1, HGF/SF incubated in the absence of olfactory bulb homogenate. Lane 2, HGF/SF incubated in the presence of olfactory bulb homogenate. Lane 3, HGF/SF incubated with olfactory bulb homogenate that was preincubated with tPA antibodies. Lane 4, HGF/SF incubated with olfactory bulb homogenate that was preincubated with a control IgG. $s c, h c$, and $l c$ refer to the single chain, heavy chain, and light chains of $\mathrm{HGF} / \mathrm{SF}$, respectively. The molecular weights in kilodaltons of protein standards are as indicated on the right. $B$, Histogram depicting mean values $\pm \mathrm{SE}(n=4)$ for several scHGF/SF cleavage experiments similar to the one shown in $A$. Iodinated scHGF/SF was incubated with olfactory bulb extract that had been pretreated with either antibodies against tPA $(+\mathrm{Ab})$ or the same amount of a nonspecific IgG preparation (control) for a period of time determined to give an $\sim 50 \%$ decrease in the scHGF/SF band in the absence of antibody treatment $(-\mathrm{Ab})$. The value obtained from an scHGF/SF band from a mock incubation was set at $100 \%$ and used to determine the percent scHGF/SF remaining in the sample.
In conclusion, in this report, we identify the components of the developing and adult olfactory system that express HGF/SF and its receptor $c$-met mRNA and demonstrate that the expression of tPA mRNA was relatively coincident within these structures. Furthermore, tPA was found to be the primary PA activity in the olfactory bulb and to constitute the bulk of exogenous proHGF/ SF-cleaving activity in bulb extracts. These results support the proposed role for tPA in regulating olfactory processes via activation of $\mathrm{HGF} / \mathrm{SF}$ in the vicinity of its receptor and provide the basis for additional research aimed at elucidating the roles of tPA and $\mathrm{HGF} / \mathrm{SF}$ in the nervous system.

\section{REFERENCES}

Bladt F, Riethmacher D, Isenmann S, Aguzzi A, Birchmeier C (1995) Essential role for the c-met receptor in the migration of myogenic precursor cells into the limb bud. Nature 376:768-771.

Brauer PR, Yee JA (1993) Cranial neural crest cells synthesize and secrete a latent form of transforming growth factor $\beta$ that can be activated by neural crest cell proteolysis. Dev Biol 155:281-285.

Brunjes PC, Frazier LL (1986) Maturation and plasticity in the olfactory system of vertebrates. Brain Res Rev 11:1-45.

Campbell PG, Novak JF, Yanosick TB, McMaster JS (1992) Involvement of the plasmin system in dissociation of the insulin-like growth factorbinding protein complex. Endocrinology 130:1401-1412.

Chan AM-L, King HWS, Deakin EA, Tempest PR, Hilkens J, Kroezen V, Edwards DR, Wills AJ, Brookes P, Cooper CS (1988) Characterization of the mouse met proto-oncogene. Oncogene 2:593-599.

Corotto FS, Henegar JA, Maruniak JA (1993) Neurogenesis persist in the subependymal layer of the adult mouse brain. Neurosci Lett 149:111-114.

Cuschieri A, Bannister LH (1975) The development of the olfactory mucosa in the mouse: light microscopy. J Anat 119:277-286.

Dent MAR, Sumi Y, Morris RJ, Seeley PJ (1993) Urokinase-type plasminogen activator expression by neurons and oligodendrocytes during process outgrowth in developing rat brain. Eur J Neurosci 5:633-647.

Farbman AI (1991) Developmental neurobiology of the olfactory system. In: Smell and taste in health and disease (Getchell TV, Doty RL, Bartoshuk LM, Snow JB, eds), pp 19-33. New York: Raven.

Friedman GC, Seeds NW (1994) Tissue plasminogen activator expression in the embryonic nervous system. Dev Brain Res 81:41-49.

Friedman GC, Seeds NW (1995) Tissue plasminogen activator mRNA expression in granule neurons coincides with their migration in the developing cerebellum. J Comp Neurol 360:658-670.

Gak E, Taylor WG, Chan AM-L, Rubin JS (1992) Processing of hepatocyte growth factor to the heterodimeric form is required for biological activity. FEBS Lett 311:17-21.

Graziadei PPC, Monti-Graziadei GA (1978) Neurogenesis and neuron regeneration in the olfactory system of mammals. I. Morphological aspects of differentiation and structural organization of the olfactory sensory neurons. J Neurocytol 8:1-18.

Hart D, Rehmetulla A (1988) Plasminogen activators and their inhibitors: regulators of extracellular proteolysis and cell function. Comp Biochem Physiol 90B:691-708.

Hinds JW (1968) Autoradiographic study of histogenesis in the mouse olfactory bulb. II. Cell proliferation and migration. J Comp Neurol 134:305-322.

Hinds JW, Hinds PL (1976) Synapse formation in the mouse olfactory bulb. I. Quantitative studies. J Comp Neurol 169:15-40.

Honda S, Kagoshima M, Wanaka A, Tohyama M, Matsumoto K, Nakamura T (1995) Localization and functional coupling of HGF and cMet/HGF receptor in rat brain: implication as neurotrophic factor. Mol Brain Res 32:197-210.

Jung W, Castren E, Odenthal M, VandeWoude GF, Ishii T, Dienes HP, Lindholm D, Schirmacher P (1994) Expression and functional interaction of hepatocyte growth factor and its receptor c-met in mammalian brain. J Cell Biol 126:485-494.

Kawasaki ES (1990) Amplification of RNA. In: PCR protocols: a guide to methods and applications (Innis MA, Gelfand DH, Seninsky JJ, White TJ, eds), pp. 21-27. San Diego: Academic.

Krystosek A, Seeds NW (1981) Plasminogen activator release at the neuronal growth cone. Science 213:1532-1534.

Laemmli UK (1970) Cleavage of structural proteins during the assembly of the head of bacteriophage T4. Nature 220:680-685. 
Lee C-C, Kozak CA, Yamada KM (1993) Structure, genetic mapping and expression of the mouse hgf/scatter factor gene. Cell Adhes Commun 1:101-111.

Lois C, Alvarez-Buylla A (1994) Long-distance neuronal migration in the adult mammalian brain. Science 264:1145-1148.

Lois C, Garcia-Verdugo J-M, Alvarez-Buylla A (1996) Chain migration of neuronal precursors. Science 271:978-981.

Luskin MB (1993) Restricted proliferation and migration of postnatally generated neurons derived from the forebrain subventricular zone. Neuron 11:173-189.

Luskin MB, Price JL (1983) The topographical organization of associational fibers of the olfactory system in the rat, including centrifugal fibers to the olfactory bulb. J Comp Neurol 216:264-291.

Mansuy IM, van der Putten H, Schmid P, Meins M, Botter F, Monard D (1993) Variable and multiple expression of protease nexin-1 during mouse organogenesis and nervous system development. Development 119:1119-1134.

Mars Wm, Zarnegar R, Michalopoulos GK (1993) Activation of hepatocyte growth factor by the plasminogen activators uPA and tPA. Am J Pathol 143:949-958.

Mars WM, Liu M-L, Kitson RP, Goldfarb RH, Gabauer MK, Michalopoulos GK (1995) Immediate early detection of urokinase receptor after partial hepatectomy and its implications for initiation of liver regeneration. Hepatology 21:1695-1701.

Moonen G, Grau-Wagemans MP, Selak I (1982) Plasminogen activatorplasmin system and neuronal migration. Nature 298:753-755.

Naka D, Ishii T, Yoshiyama Y, Miyazawa K, Hara H, Hishida T, Kitamura N (1992) Activation of hepatocyte growth factor by proteolytic conversion of a single chain form to a heterodimer. J Biol Chem 267:20114-20119.

Nakamura T, Nishizawa T, Hagiya M, Seki T, Shimonishi M, Sugimura A, Tashiro K, Shimizu S (1989) Molecular cloning and expression of human hepatocyte growth factor. Nature 342:440-443.

Naldini L, Tamagnone L, Vigna E, Sachs M, Hartmann G, Berchmeier W, Daikuhata Y, Tsubouch H, Blas F, Comoglio PM (1992) Extracellular proteolytic cleavage by urokinase is required for activation of hepatocyte growth factor/scatter factor. EMBO J 11:4825-4833.

Noda M, Harada Y (1981) Development of olfactory epithelium in the mouse: scanning electron microscopy. Biomed Res [Suppl] 2:449-454.

O'Shea KS, Dixit VM (1988) Unique distribution of the extracellular matrix component thrombospondin in the developing mouse embryo. J Cell Biol 107:2737-2748.

Pinching AJ, Powell TPS (1971) The neuropil of the periglomerular region of the olfactory bulb. J Cell Sci 9:379-409.

Pittman RN (1985) Release of plasminogen activator and a calciumdependent metalloprotease from cultures sympathetic and sensory neurons. Dev Biol 110:91-101.

Rubin JS, Bottaro DP, Aaronson SA (1993) Hepatocyte growth factor/ scatter factor and its receptor, the $c$-met proto-oncogene product. Bio- chim Biophys Acta 1155:357-371.

Saksela O, Rifkin D (1988) Cell associated plasminogen activation: regulation and physiological functions. Annu Rev Cell Biol 4:93-126.

Sambrook J, Fritsch EF, Maniatis T (1989) Molecular cloning: a laboratory manual, Ed 2. New York: Cold Spring Harbor Laboratory.

Santos OF, Barros EJG, Yang X-M, Matsumoto K, Nakamura T, Park M, Nigam SK (1994) Involvement of hepatocyte growth factor in kidney development. Dev Biol 163:525-529.

Sappino A-P, Madani R, Huarte J, Belin D, Kiss JZ, Wohlwend A, Vassalli J-D (1993) Extracellular proteolysis in the adult murine brain. J Clin Invest 92:679-685.

Schmidt C, Bladt F, Goedecke S, Brinkmann V, Zschiesche W, Sharpe M, Gherardi E, Birchmeier C (1995) Scatter factor/hepatocyte growth factor is essential for liver development. Nature 373:699-702.

Seeds NW, Haffke S, Krystosek A (1980) Cell migration and recognition in cerebellar reaggregate cultures. In: Tissue culture in neurobiology (Giacobini E, ed) pp 145-154. New York: Raven.

Seeds NW, Haffke S, Christensen K, Schoonmaker J (1990) Cerebellar granule cell migration involves proteolysis. In: Molecular aspects of development and aging of the nervous system (Lauder JM, ed), pp 169-178. New York: Plenum.

Seeds NW, Haffke S, Hawkins R, Krystosek A, McGuire P, Verrall S (1992) Neuronal growth cones: battering rams or lasers? In: The nerve growth cone (Kater SB, ed), pp 219-228. New York: Raven.

Sonnenberg E, Weidner KM, Birchmeier C (1993) Expression of the c-met receptor and its ligand during mouse embryogenesis. In: Hepatocyte growth factor-scatter factor (hgf-sf) and the c-met receptor (Goldberg ID, Rosen EM, eds), pp 381-395. Basel: Birkhäuser.

Thewke DP, Seeds NW (1995) Coexpression of hepatocyte growth factor, its receptor (c-met), and tissue-type plasminogen activator in murine brain. Soc Neurosci Abstr 21:2011

Uehara Y, Minoa O, Mori C, Shiota K, Kuno J, Noda T, Kitamura N (1995) Placental defect and embryonic lethality in mice lacking hepatocyte growth factor/scatter factor. Nature 373:702-705.

Verrall S, Seeds NW (1989) Characterization of ${ }^{125}$ I-tissue plasminogen activator binding to cerebellar granule neurons. J Cell Biol 109:265-271.

White EL (1973) Synaptic organization of the mammalian olfactory glomerulus: new findings including an intraspecific variation. Brain Res 60:299-313.

Woolf AS, Kolatsi-Joannou M, Hardman P, Andermarcher E, Moorby C, Fine LG, Jat PS, Noble MD, Gherardi E (1995) Roles of hepatocyte growth factor/scatter factor and the met receptor in the early development of the metanephros. J Cell Biol 128:171-184.

Wong V, Song Y, Arriaga R, Lindsay RM (1995) CNTF Potentiates the effects of bdnf, gdnf, or hgf in cultured motor neurons. Soc Neurosci Abstr 21:1535. 